\title{
The Competence of Greek High School Students at the End of Compulsory Education in Language Use
}

\author{
Konstandinos P. Garavelas \\ University of Ioannina, Greece \\ Email: garavelask@yahoo.gr
}

\begin{abstract}
In this article I intend to focus on the discussion pertaining to communicative competence regarding reading competence and specific reading skills. In particular, this paper investigates whether and to what extent the progress on language use is differentiated in relation to factors as sex, place of residence, social position and use of a language other than Greek at home. The experiment presented here took place in the scholar seasons 2004/05 and 2005/06 and examined572 pupils of the $3^{\text {rd }}$ class of Greek High school. These were divided into equal numbers of participants residing in i) a Greek city of more than 1000000 residents (Thessaloniki) ii) a Greek city of about 100000 residents (Ioannina) and iii) Greek villages of 1 to 5000 residents. Data was obtained by means of a test especially designed for the purposes of this work, namely to evaluate student reading skills. The results have shown that the progress in language use is related to student place of residence and social position but is not affected by factors like sex and use of a language other than Greek at home.
\end{abstract}

Index Terms-language teaching, communicative competence, language use, sociolinguistic, compulsory education

\section{The Two Dimensions of LAnguage}

Language use has not always been the target of foreign language teaching. Until about four decades ago, the interest of language teaching focused on ancient languages and literature. The way languages like ancient Greek and Latin were treated was transferred to the teaching of modern languages and thereby to the teaching of Modern Greek. The burden fell on teaching grammar, so that knowledge of language meant knowledge of grammar.

Saussure was the first to propose in 1916 that language is a social institution, emphasizing thereby the social character of language and suggesting the dichotomy of language/speech (langue/parole) (Saussure, 1979). Saussure's dichotomy is related to Chomsky's distinction between language competence and language performance. Chomsky defined linguistic performance as the way that one uses his linguistic skills in daily communication situations (Babiniotis, 1977). Performance is defined as a set of skills, but it is also influenced by psychological and physiological factors (e.g. fatigue, drunkenness, boredom among others) mood, perceptions of the speakers for their interlocutors etc. (Pavlidou 1991).

Communicative competence appeared in languages teaching in the late 70's and has been affected by disciplines such as ethnography of communication, psychology, sociolinguistics, social anthropology, philosophy of language, etc.. This new trend has led to diversification of the way modern languages are taught. So, while previously language was identified as a system of words and grammar, the focus is now on the operation of this system and its use by the speaker. This means that knowledge coexists with language use.

The science dealing with linguistic communication and communicative competence is ethnography of communication. The scientist who established it was the American anthropologist Dell Hymes, who argued that any linguistic approach having an interest only to analyze the structure of language as a code, would neglect its social importance, variety and uses. So Hymes between the 60s and 70s strongly supported that it is necessary for language to be studied in relation to the laws that govern and support a communicative situation. He developed his theory during his research on American Indian communities, using the method of observation of linguistic events in their linguistic environment.

Hymes emphasizes the meaning of communicative competence, a broader concept under which Chomsky's linguistic competence is subsumed. Communicative competence is realized as a direct effect on linguistic environment. If one wants to communicate effectively, he needs to know how to connect the received or produced message with the social factors that determine the speech situation. Hymes has proposed an ethnographic framework which takes into account the various factors that are involved in speaking. The Ethnography of a communicative event is a description of all factors that are relevant in understanding how that particular communicative event achieves its objectives. Hymes used the word SPEAKING as an acronym for the various factors he deems to be relevant (Hymes, 1971). These are:

S: Setting and Scene 


\section{P: Participants \\ E: Ends \\ A: Acts \\ K: Key \\ I: Instrumentalities \\ N: Norms) \\ G: Genre}

With the model of SPEAKING Hymes underlines, that communication is a complex activity and that even a special piece of speech is a "piece of specialized work." A speaker successful in communication needs to take into account the eight afore mentioned factors. When something goes wrong in the communicative act, which is often, speakers usually fail to meet some of these conditions. Since we acknowledge that there are "better" speakers and "poorer" speakers, we may also assume that individuals vary in their ability to manage and exploit the total array of the factors involved (Wardhangh 1992).

The importance of communicative skills is related with the functional character of language. This is most prominently expressed by Beser and Kreuder in the following: "We do not understand language as a standardized inventory of signs and rules, but language is our most important medium of communication between people. People communicate with each other in exchanging messages based on their internal world for the purpose of meeting needs and for the fulfilment of interests. Without communication, no interaction is possible (Beser and Kreuder, 1975, p. 15). ${ }^{1 \text { ", }}$ Accordingly, two things are the most important points of language learning: firstly the skills that need to be developed, because they will allow the student to act effectively in cases of communication, and, secondly, classroom communication which will provide the student with appropriate learning opportunities.

Some years later Greek researchers have also maintained the double dimension of language. Tokatlidou (1986) specifically argued that communicative competence has a linguistic and extralinguistic dimension. Consequently we are not only interested in language acquisition in the terms of correct application of formal rules, which actually is the acquisition of a system, but rather in the selection of a type appropriate for each occasion, namely the application of the linguistic system for communication. Haralambopoulos and Hatzisavidis (1997) also support that language structure and use are interrelated and influence each other. Athanasiou (1998) explains that knowledge of a language entails among others the knowledge of the grammar, the syntax, the etymology, as well as production of a language. Using the language, on the other hand, is the ability to put these skills into use for communicative purposes in various circumstances. The basic principle of this new theoretical approach is that each teaching program must be focused on students. More specifically, the decisive criterion for the design of a language teaching program in every aspect (materials, technical, etc.) is the pupil, and especially his social and linguistic needs, his previous education and his cultural background (Tokatlidou 1986).

Today, the communicative approach is the main method of the foreign language teaching. Since 2000 the teaching process has been supported by the Common European Framework of Reference for the language, which is adopted by the Council of Europe ${ }^{2}$. This version was released in several languages (among them Greek ${ }^{3}$ ) and includes guidelines for language teaching. In focus is the use of language and therefore the approach treats language users and language learners primarily as 'social factors', who must carry out communicative tasks (which are not necessarily associated with language) in a given set of circumstances, in a particular environment and in a particular field.

\section{THE RESEARCH}

\section{A. Methodology}

This paper is part of a wider research and investigates whether and to what extent the progress on language use is differentiated in relation to factors as sex, place of residence, social position and use of a language other than Greek at home. It took place in the scholar seasons 2004/05 and 2005/06 and examined pupils of the $3^{\text {rd }}$ grade of Greek High school (this point signifies the end of the compulsory education in Greece). In order to meet this objective I took a sample of 572 Greek High school students. These students were divided into equal numbers of participants residing in a Greek city of more than 1000000 residents (Thessaloniki), a Greek city of about 100000 residents (Ioannina) and Greek villages of 1 to 5000 residents.

To the best of my knowledge a similar research, that focuses on the end of compulsory education (the third class of high school) and evaluates only the communicative skills of students through daily texts, had not been carried out for

\footnotetext{
${ }^{1}$ The German text is: "Wir verstehen Sprache nicht als genormtes Inventar von Zeichen und Verknüpfungsregeln, sondern Sprache ist für uns das wichtigste Mittel der Verständigung zwischen Menschen. Indem Menschen Nachrichten austauschen und auf ihre äußere Welt zum Zwecke der Befriedigung von Bedürfnissen auf dem Erfüllen von Interessen entwirken, kommunizieren sie miteinander. Ohne Kommunikation ist keine Interaktion denkbar'' (Beser and Kreuder, 1975, p.15).

${ }^{2}$ http://www.coe.int/t/dg4/linguistic/Source/Framework_EN.pdf

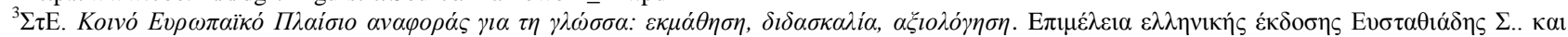

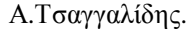


Greek in Greece by the time of conducting the current study ${ }^{4}$. Therefore I had to design a new assessment tool, a language test, under which the questions raised by this research could be addressed. This consists of six (6) texts from magazines and newspapers and includes twenty-five (25) questions (18 closed and 7 open-type questions). The criterion for the selection of the texts was the theory of the Domains of Language Behavior from the field of language sociology (Fishman, 1975). In the present investigation I chose to use six texts from six (6) different domains of daily speech from the daily life. These are the domains of news, science, art, public affairs and administration, economics and sports. It should be noted that texts from these domains appear in the students' school course books. The exercises in this language test have been based on the Tsopanoglou's typology (Tsopanoglou, 2000), which is used by the Greek Ministry of Education in the Greek foreign language tests (i.e. KPG: see http://www.ypepth.gr/kpg). The entire test and especially the criteria (i.e. the indicators) for student communicative competence were based on the communicative theory of Hymes and on the language teaching curriculum in Greek secondary (high school) education ${ }^{5}$.

The variables relevant for this study are sex, place of residence, language use at home and social status of students. In what follows I will briefly describe how the different categories of social status were defined and used in this work. Social status was assumed to be comprised of two aspects: parents' occupation and level of education. Regarding the first aspect there were four categories and each was given a value as follows:

1. farmers and household

2. technical occupations (crafts) and small business owners.

3. state clerks and private sector employees

4. executives, doctors, lawyers, university teachers, judges.

As for the second aspect, level of education, there were three categories assigned values as follows:

1. primary school and junior high school

2. high school and technological schools

3. college and university

The values of both parents' occupation and level of education were added and the resulting rate represented participant social status on the whole. For example a student whose parents were state clerks with university degrees would be given a12 rating which belongs to the high level. According SPSS, 4-7 is social status of low level, 8-9 is social status of middle level and 10-14 is social status of high level.

The tests had to be completed by the pupils within two (2) school hours (two sessions of forty-five (45) minutes) each and were subsequently collected by the test administrator to ensure the validity of the research. The participants retained their anonymity. A quantitative analysis was conducted on the data by me with the statistical package SPSS 12.

\section{B. Results}

The results will be presented in four subsections each corresponding to one of the variables studied. The sections that follow is present whether and to what extent the progress on language use is differentiated in relation to factors as sex, place of residence, social position and use of a language other than Greek at home.

\section{Total performance in language use}

The following Table shows participant overall performance with respect to language use.

TABLE 1:

AVERAGE IN LANGUAGE USE

\begin{tabular}{|l|l|l|l|l|l|l|l|l|}
\hline $\mathbf{N}$ & average & Standard deviation & $\mathbf{2 0}$ & $\mathbf{4 0}$ & $\mathbf{6 0}$ & $\mathbf{8 0}$ & Minimum value & Maximum value \\
\hline 312 & 17,35 & 3,53 & 14 & 16,2 & 19 & 20 & 8 & 26 \\
\hline
\end{tabular}

A first observation considering the overall results in the language use, as presented in Table 1, is that the average performance of students is 17.35 ( $\mathrm{SD}=3.53$ ). The minimum value was found to be 8 and the maximum 26. Regarding score distribution it is worth mentioning that a high percentage (around 40\%) gave scores less or equal to the half of the maximum possible performance (32), which we believe constitutes unsatisfactory performance.

\section{Performance in language use in relation to sex}

The table below shows the average performance in language use in relation to the gender of the students.

TABLE 2.

AVERAGE IN LANGUAGE USE IN RELATION TO SEX

\begin{tabular}{|l|l|l|l|l|l|l|l|l|l|}
\hline gender & $\mathbf{N}$ & average & $\begin{array}{l}\text { Standard } \\
\text { deviation }\end{array}$ & $\mathbf{2 0}$ & $\mathbf{4 0}$ & $\mathbf{6 0}$ & $\mathbf{8 0}$ & $\begin{array}{l}\text { Min.-Max. } \\
\text { value }\end{array}$ & $\begin{array}{l}\text { Mann-Whitney U } \\
\text { (p-value) }\end{array}$ \\
\hline male & 141 & 16,91 & 3,54 & 14 & 16 & 19 & 20 & $8-25$ & 10549,50 \\
female & 170 & 17,70 & 3,49 & 15 & 17 & 19 & 20 & $8-26$ & $(0,068)$ \\
\hline
\end{tabular}

These findings indicate that female students had a better performance than male students. An analysis with the MannWhitney U test showed that these differences were not significant, but approached significance $(\mathrm{p}=0,068)$. Regarding

\footnotetext{
${ }^{4}$ The PISA survey is a broader comparative research between countries belonging to the Organization for Economic Cooperation and Development (OECD). It focuses on the reading skills of students in the broadest sense and includes the capacity to cope with literary and theatrical texts, graphs, tables, etc.

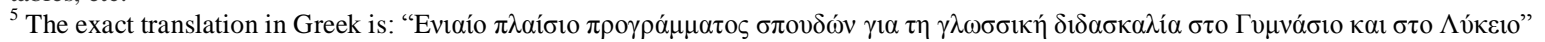


the allocation of the students we can find a rate equal to $40 \%$ of the male students that shows performance equal to or less than the half of the highest possible performance (32). Conversely this percentage in the female students is somewhat lower. Additionally, the rate of the students from both groups (male and female), who scored more than 20 is 1 to $5(20 \%)$ which is considered a low percentage. This demonstrates a lag in the language use for both groups.

\section{Performance in language use in relation to place of residence}

In what follows we will proceed to the results from the average performance of students in relation to area of residence (Tables 4 and 5). Table 4 shows the performance of students in each region separately, while Table 5 has two categories: 'urban' (students from Thessaloniki and Ioannina), and 'non-urban' (students from rural areas in the prefecture of Ioannina).

TABLE 3:

AVERAGE IN LANGUAGE USE IN RELATION TO PLACE OF RESIDENCE

\begin{tabular}{|l|l|l|l|l|l|l|l|l|l|}
\hline Place of residence & $\mathbf{N}$ & Average & $\begin{array}{l}\text { Standard } \\
\text { deviation }\end{array}$ & $\mathbf{2 0}$ & $\mathbf{4 0}$ & $\mathbf{6 0}$ & $\mathbf{8 0}$ & $\begin{array}{l}\text { Min.-Max. } \\
\text { value }\end{array}$ & $\begin{array}{l}\text { Kruskal-Wallis } \\
\text { (p-value) }\end{array}$ \\
\hline Thesaloniki & 107 & 17,85 & 3,41 & 15 & 17 & 19 & 20 & $8-26$ & \\
\hline Ioannina & 111 & 17,75 & 3,72 & 14.4 & 17 & 19 & 21 & $8-25$ & $\begin{array}{l}12,854 \\
(\mathbf{0 , 0 0 2}) \\
\text { Region of Ioannina } \\
\text { (villages) }\end{array}$ \\
\hline
\end{tabular}

TABLE 4:

AVERAGE IN LANGUAGE USE IN RELATION TO PLACE OF RESIDENCE (URBAN VS. RURAL

\begin{tabular}{|l|l|l|l|l|l|l|l|l|l|}
\hline $\begin{array}{l}\text { Place of } \\
\text { residence }\end{array}$ & $\mathbf{N}$ & average & $\begin{array}{l}\text { Standard } \\
\text { deviation }\end{array}$ & $\mathbf{2 0}$ & $\mathbf{4 0}$ & $\mathbf{6 0}$ & $\mathbf{8 0}$ & $\begin{array}{l}\text { Min.-Max. } \\
\text { value }\end{array}$ & $\begin{array}{l}\text { Mann-Whitney U } \\
\text { (p-value) }\end{array}$ \\
\hline urban & 218 & 17,80 & 3,56 & 14,4 & 17 & 19 & 20 & $8-26$ & $\mathbf{7 6 3 8 , 5 0}$ \\
\hline Rural & 94 & 16,32 & 3,23 & 13 & 15 & 17 & 20 & $10-24$ & $\mathbf{( < 0 0 1 )}$ \\
\hline
\end{tabular}

As we can see from the Tables above, the analysis based on the variable "Place of Residence" leads to important conclusions ( $p$ value in table 3 is 0,002 and in table $4<0,001$ ). In particular there is a highly significant main effect of this variable. Namely, we found that the students from the two cities were significantly more successful that the students from the rural areas. Additional comparisons on the above scores showed that the average of the students of Thessaloniki is approximately equal with the average of the students of Ioannina.

On the whole, the performance of students from rural areas is significantly lower compared with the performance of students from urban, which lends additional support to the findings that the variable of Place of Residence has a main effect on student performance. Based on these findings we can maintain that table 5 confirms the results of table 4 and, where the primacy of the urban environment is evident, that relevance is statistically significant $(\mathrm{p}<0,001)$.

4. Performance in language use in relation to social position

Table 5 illustrates the average in language use in relation to social position.

TABLE 5:

AVERAGE IN THE USE OF LANGUAGE IN RELATION TO SOCIAL POSITION

\begin{tabular}{|l|l|l|l|l|l|l|l|l|l|}
\hline $\begin{array}{l}\text { Social } \\
\text { position }\end{array}$ & $\mathbf{N}$ & Average & $\begin{array}{l}\text { Standard } \\
\text { deviation }\end{array}$ & $\mathbf{2 0}$ & $\mathbf{4 0}$ & $\mathbf{6 0}$ & $\mathbf{8 0}$ & $\begin{array}{l}\text { Min.-Max. } \\
\text { value }\end{array}$ & $\begin{array}{l}\text { Kruskal-Wallis } \\
\text { (p-value) }\end{array}$ \\
\hline Low & 103 & 16,36 & 3,39 & 13 & 15 & 17 & 20 & $9-24$ & \multirow{3}{3}{30,520} \\
middle & 115 & 16,98 & 3,55 & 14 & 16 & 18 & 20 & $8-26$ & $(<0,001)$ \\
\hline High & 94 & 18,89 & 3,14 & 17 & 19 & 20 & 21 & $8-25$ & \\
\hline
\end{tabular}

The above analysis yielded a significant main effect of the factor of Social Position on the Performance regarding language use. In particular the students from the higher social position achieved the best performance and the students from the other two groups followed with a big difference. Continuing with the distribution of the students, the data has suggested that the pupils of the middle and the lower social position seem to have several difficulties in language use since almost $40 \%$ of them (in students from the lower social position the rate is somewhat higher) have a performance equal to or less than the half of the highest possible performance (32). In addition, the portion from the low and the middle social groups who achieved more than 20 in the test was small (only 20\%).

\section{Performance in language use in relation to use of a language other than Greek at home}

Let us examine now the last variable incorporated in this research. Table 6, that follows, shows the average performance in the use of Greek as this was affected by the use of another language at home.

TABLE 6:

AVERAGE IN LANGUAGE USE IN RELATION TO THE USE OF A LANGUAGE OTHER THAN GREEK AT HOME

\begin{tabular}{|l|l|l|l|l|l|l|l|l|l|}
\hline $\begin{array}{l}\text { Use of another } \\
\text { language }\end{array}$ & $\mathbf{N}$ & average & $\begin{array}{l}\text { Standard } \\
\text { deviation }\end{array}$ & $\mathbf{2 0}$ & $\mathbf{4 0}$ & $\mathbf{6 0}$ & $\mathbf{8 0}$ & $\begin{array}{l}\text { Min.-Max. } \\
\text { value }\end{array}$ & $\begin{array}{l}\text { Mann-Whitney U } \\
\text { (p-value) }\end{array}$ \\
\hline yes & 39 & 16,64 & 2,9 & 14 & 16 & 18 & 19 & $8-22$ & 4531,5 \\
\hline no & 273 & 17,45 & 3,6 & 14 & 17 & 19 & 20 & $8-26$ & $-0,131$ \\
\hline
\end{tabular}

Observing the scores in Table 6 it must be noted that this factor does not seem to be significantly related to the performance of children concerning language use. Students, who reported that they are not using another language to 
communicate at home, may have a higher performance, but this difference is not statistically significant, (p-value is 0,131). Concerning the allocation of the students a percentage close to $40 \%$ from both groups have scored less than or equal to the half of the maximum possible performance (32), which is not satisfactory.

\section{CONCLUSIONS}

Concluding this paper we will provide a summary of the findings. The results from the present study show that there is not a main effect of the variables Sex and Use of a language other than Greek at home on the student competence in language use. In contrast it was found that there are students who lag in performance because they live in rural areas or because they come from a lower social class. This means that language courses in Greek schools do not seem to be organized in a way that allows all groups of students to develop the same level of linguistic ability regarding reading competence. If these results are valid there are negative consequences for these students. If we take into account that the school's role is to help students in future social and professional choices, something which is decisive for their lives, our results suggest that there are not equal opportunities for all students in these areas.

Based on the above, we think that it is evident that the teaching of language courses in Greek schools needs to be altered. The first step is that the Greek Ministry of Education must realize that students come from different backgrounds and, therefore, they do not have the same needs. Should this happen, changes in teaching materials and in the monitoring of the teaching programs must follow. First of all, the materials for the language course should not be based exclusively on specific books, but teachers must have the possibility to choose authentic language materials addressing the needs of their students, on the condition that this material serves a specific educational goal. This is a necessary requirement for the students to become familiarized with the linguistic forms of everyday communication. Children who experience a social and family environment poor in stimuli need this even more. Additionally, authentic language materials have to be accompanied by communicative activities which will refer to real communication and not only to linguistic structures. Only when all the above are realized will students be able to use the language effectively. Language programs in Greece may in theory be communicative but the monitoring of their implementation is either defective or absent (Gotowos, 2003). In fact often there is not a correspondence between the program conditions and classroom activities. Consequently this could lead to a failure to meet the primary goals of teaching.

Concluding, since the language programs in Greece have taken into account these parameters in their original design, the correct implementation of them could be the answer to the problem.

\section{ACKNOWLEDGEMENTS}

I would like to thank my supervisor Prof. Gotowo Athanasio for the invaluable advice and guidance in the preparation of this work. I am grateful to the other members of the supervising committee Prof. Athanasiou Leonida for useful comments and ideas on earlier versions of this paper. I am also grateful to the participants of this study and the Prof. Tokatlidou Vassiliki who granted me permission to conduct the experiment. All mistakes and misinterpretations remain my own.

\section{REFERENCES}

[1] Athanasiou, L. (1998). Language - language communication and teaching in primary and secondary education. Ioannina: self published.

[2] Babiniotis, G. (1977). Genetic-transformational grammar ( $\alpha$ brief introduction). Athens: self published.

[3] Beyer, K. \& H. D. Kreuder (1975). Lernziel: Kommunikation. Stuttgart: W. Kohlhammer Verlag.

[4] Council of Europe. (2000). Common European framework of reference for languages: learning, teaching, assessment. http://www.coe.int/t/dg4/linguistic/Source/Framework_EN.pdf (accessed at 27/09/2011).

[5] Council of Europe. (2008). Common European framework of reference for languages: learning, Teaching, assessment. Greek version. Editors of Greek version Efstatiades S. and A. Tsagalides.

[6] Gotowos, E. A. (2003). The rationale behind real school. Second reprint. Athens: Gutenberg.

[7] Hymes, D. (1971). On communicative competence. In Pride, J.\& Holmes, J. (eds.), Sociolinguistics: Selected readings. Harmondsworth: Penguin, 269-293.

[8] Pavlidou, Th. (1991). Levels of linguistic analysis. Thessaloniki: Aristotelian University Publication Services.

[9] Saussure, F. de (1916). Cours de linguistique générale. Paris\&Lausanne: Payot.

[10] Saussure, F. de. (1979). Courses of general linguistics. Greek tranlation: Apostolopoulos F.D.. Athens:Papazisis.

[11] Tokatlidou, V. (1986). Introduction to modern language teaching. Athens: Odysseas.

[12] Tsopanoglou, A. (2000). Methodology of scientific research and applications in the evaluation of language training. Thessaloniki: Ziti.

[13] Wardhangh, R. (1992). An Introduction to sociolinguistics. $2^{\text {nd }}$ Edition. Oxford: Blackwell.

[14] Haralambopoulos, A. \& S. Hatzisavidis (1997). Teaching the functional use of language: theory and practice. Thessaloniki: Kodikas. 


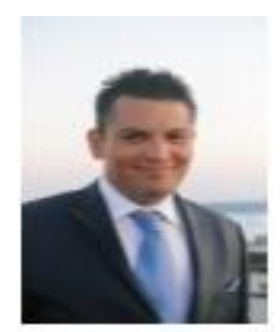

Konstandinos P. Garavelas was born in Ioannina, Greece in 1974. He was awarded holds a bachelor in German Language and Literature and an MA in Language Teaching from the Aristotle University of Thessaloniki in 1996 and 2001 respectively. His $\mathrm{PhD}$ in the department of Philosophy, Pedagogy and Psychology, University of Ioannina was completed in 2010. He focused on the communicative approach to language teaching.

Since 2008 up to date he is permanent staff in state secondary schools in Ioannina, Greece. From 1999 up to present he has been a scientific associate in the Technological Institute of Epirus. Publications: Garavelas, K. (2010). The communicative competence of students at the end of compulsory education: the case of understanding written texts. Nea Paideia 138, 84-94. Garavelas, K. (2008). The use of language games in foreign language teaching in tertiary education: the case of role play. In Vlachopoulos, S. \& T. Gogas (eds.) Proceedings of the Second International Conference on Foreign Language Teaching in Tertiary Education. Ioannina: Carpe Diem, 207-219. Garavelas, K. (in print). The existence of complex creative cognitive activities in foreign course books: the case of Deutch ein Hit! 1. Proceedings of the International Conference on Language and Cultures in (Inter) Action.

Research interests: language teaching, communicative competence, teaching German as a foreign/second language and sociolinguistics. 